\title{
Lung Obstructive Function Score 1
}

National Cancer Institute

\section{Source}

National Cancer Institute. Lung Obstructive Function Score 1. NCI Thesaurus. Code C131056.

FEV1 60-79\%. 